\title{
Pandangan Penonton Tentang Wayang Kulit di Kanal Youtube
}

\section{Viewer's Perspectives of Leather Shadow Puppet Performances on Youtube Channel}

\author{
Joyo Nur Suryanto Gono, Wiwied Noor Rakhmad \\ Departemen Ilmu Komunikasi, Fakultas Ilmu Sosial dan Ilmu Politik, Universitas \\ Diponegoro \\ Alamat: Jalan Professor Soedarto SH, Tembalang, Kec. Tembalang, Kota Semarang, \\ Indonesia 50139 \\ Email:jnsgono@gmail.com
}

\begin{abstract}
Abstrak
Studi ini mengungkapkan fenomena tentang pertunjukan wayang kulit yang sepi penonton di Indonesia. Nanun kini, ketika wayang kulit di upload lewat Youtube, nampaknya timbul peningkatan penonton. Fenomena ini menarik dikaji lebih mendalam. Ketika wayang kulit dalam format youtube ini muncul istilah dalang viral. Dalang wayang kulit yang dianggap paling viral saat ini adalah Ki Seno Nugroho dari Yogyakarta, karena dalang ini memiliki paling banyak penggemar dan paling laris di antara dalang wayang kulit yang lain. Bagaimana pengalaman dan pandangan penonton dalam menonton wayang kulit melalui youtube memahami nilai-nilai sosial dalam pertunjukan wayang kulit Ki Seno Nugroho? Studi ini menggunakan metode fenomenologi. Observasi dilakukan proses dalang viral sedang melakukan pertunjukan wayang kulit. Informan yang diwawancarai budayawan, tokoh masyarakat, penonton, pengrawit. Penelitian ini menunjukkan hasil bahwa, Dalang Seno disebut sebagai dalang viral, memiliki kemampuan membangun cerita secara ringkas (padat), menceritakan perlawanan "abdi" terhadap raja, sehingga tidak membosankan, membangun gending garapan, tanpa tambahan musik modern, yang menarik pagelaran wayang kulit via youtube ini melibatkan semua unsur, yaitu melibatkan dialog saat adegan "limbukan" atau "adegan goro-goro", antara Dalang, Pesinden, Pengrawit, Crew film. Performansi dalang Seno dari dialog, sabetan, selalu menarik perhatian penonton. Pandangan penonton bahwa Dalang Seno mengutamakan pertunjukan wayang kulit dominan sebagai fungsi menghibur, sehingga nilai-nilai sosial yang disimbolkan dari wayang kulit tidak menonjol.
\end{abstract}

Kata Kunci: Dalang Viral, wayang kulit, pandangan penonton, nilai-nilai sosial, fungsi hiburan, kanal youtube.

\begin{abstract}
This study reveals the phenomenon of leather shadow puppet performances that have no audience in Indonesia. But now, when leather shadow puppet is uploaded via Youtube, there seems to be an increase in viewership. This phenomenon is interesting to be studied in more depth. When leather shadow puppet is in youtube format, the term viral mastermind appears. The puppeteer who is considered the most viral at the moment is Ki Seno Nugroho from Yogyakarta, because this puppeteer has the most fans and is the best-selling among other puppeteers. How do the experiences and views of the audience in watching leather shadow puppet through youtube understand the social values in Ki Seno Nugroho's shadow puppet show? This study uses a phenomenological method (Cresswell, 2014). Observations are carried out the process of viral puppeteers doing a puppet show of leather. Informants interviewed is culture observer public figures, viewer, the traditional musician. This research shows the results that Dalang Seno has the ability to build a concise (solid) story, tells the resistance of "servants" to the king, so that it is not boring, builds arable music, without the addition of modern music, which is interesting in this leather shadow puppet performance via youtube involving all elements, which involves dialogue during the "limbukan" or "goro-goro" scenes, between the Dalang, Pesinden, Pengrawit, and Crew films. The puppeteer Seno's performance from the dialogue, the sabetan, always attracts the attention of the audience. The view of the audience is that Dalang Seno prioritizes the dominant shadow puppet show as an entertaining function, so that the social values symbolized by leather shadow puppet do not stand out.
\end{abstract}

Keywords: Dalang Viral, Leather Shadow Puppet, Viewers' Perspectives, Social Values, Entertain Function, Youtube 
Biokultur, 2021, 10 (2): 107-119. DOI: http://dx.doi.org/10.20473/bk.v10i2.31265

Article History:

Received November 10, 2021; Accepted November 29, 2021; Published Online December 22, 2021.

\section{Pendahuluan}

Menonton pertunjukan wayang kulit melalui kanal youtube pada era digital merupakan fenomena menarik untuk dikaji lebih jauh. Berdasarkan observasi peneliti, ternyata jumlah penonton pertunjukan wayang kulit secara langsung sepi penonton pada beberapa tahun terakhir. Namun ketika pertunjukan wayang kulit diupload ke kanal youtube, jumlah penonton yang antusias menonton relative besar. Padahal menonton wayang kulit itu memerlukan penghayatan cukup dalam. Muatan nilai-nilai dalam pagelaran wayang menggambarkan nilainilai kehidupaan sehari-hari di masyarakat, menempatkan diri pada tempat yang telah ditentukan oleh Tuhan. Peran Dalang sangat besar untuk mensosialisasikan nilai-nilai sosial yang terkandung dalam cerita wayang kulit agar bisa diterima dan diresapi penonton, menjadi tuntunan hidup manusia pada umumnya.

Sementara itu UNESCO telah mengakui wayang kulit sebagai World Master Piece of Oral and Intangible Heritage of Humanity pada tanggal 07 November 2003. Pengakuan ini menurut I Gede Ardika sangat berarti bagi bangsa Indonesia bahwa wayang sebagai budaya bangsa yang diwarisi dari leluhur itu mendapat pengakuan dunia. Sebagai Master Piece, wayang mengandung nilai yang sangat tinggi yang diakui oleh masyarakat dunia. Niscaya wayang akan mengangkat citra bangsa, nama bangsa, harkat dan martabat bangsa di forum dunia (Ardika, 06 Maret 2010, https://wayang.wordpress.com/2010/jam 9.15). Pengakuan ini merupakan tugas berat bagi bangsa karena persoalan sosialisasi dan pengembangan wayang kulit sebagai seni pertunjukan di masa kini.

Wayang Kulit (Purwo) merupakan seni tradisi yang berbasis pada Budaya Jawa bisa disaksikan secara live maupun rekaman melalui youtube. Sekalipun mengalami berbagai perkembangan format pertunjukan dan isi cerita untuk beradaptasi dengan perkembangan selera penonton, tetapi seni pertunjukan wayang kulit yang sudah berumur ratusan tahun ini hingga kini masih menjadi seni pertunjukan yang digemari penonton. Melalui youtube, hampir semua seni pertunjukan wayang kulit diunggah secara live dan rekaman. Mulai dari Dalang kondang dari Jawa Tengah Ki Anom Suroto, Ki Manteb Sudarsono, Ki MPP Bayu Aji, Ki Seno Nugroho, Ki Purbo Asmoro, Ki Cahyo Kuntadi dan lain-lain, hingga Dalang dari Jawa Timur Ki H. Sukron Suwondo, Ki Anom Dwijo Kangkow, Ki Eko Kondo Prisdianto, Ki Sun Gondrong, Ki Minto Darsono, Ki Rudi Gareng, dan lain-lain. Para Dalang tersebut telah mempersiapkan peralatan selain peralatan mendalang seperti seperangkat Wayang Kulit, seperangkat Gamelan pengiring, Kelir, Lampu, juga peralatan untuk dokumentasi video dan fotografi dan komputer yang menggunakan WiFi untuk mengunggah pertunjukan wayang kulit.

Penelitian mutakhir mengenai pertunjukan wayang kulit dilakukan oleh Sholikhatun Ni'mah berjudul Respon Generasi Muda Jawa Terhadap Seni Pertunjukan Wayang Kulit (Studi Kasus di Desa Lemah Ireng, Kecamatan Bawen, Kabupaten Semarang (2016). Penelitian ini membahas fenomena keberadaan pertunjukan wayang kulit di sebuah desa bernama Lemah 
Ireng, Kecamatan Bawen, Kabupaten Semarang, yang banyak ditonton oleh generasi muda desa tersebut. Fokus perhatiannya tertuju pada respon generasi muda, dan faktor-faktor yang melatar belakangi menonton seni pertunjukan wayang di desa itu. Pembatasan konsep respon dalam penelitian adalah suatu persepsi, atau sikap, tanggapan, ekspresi terhadap seni pertunjukan wayang kulit yang menghasilkan reaksi berupa tindakan. Penelitian ini menyimpulkan bahwa pertunjukan wayang kulit di Desa Lemah Ireng merupakan instrumen penting dalam upacara bersih desa, sehingga eksistensinya terjaga dengan baik. Pertunjukan wayang kulit merupakan usaha untuk memelihara hubungan antara masyarakat desa dengan danyang atau leluhurnya. Penonton wayang kulit generasi muda mempunyai respons yang baik terhadap pertunjukan wayang kulit. Sekalipun demikian fungsi wayang kulit bagi penonton muda mengalami pergeseran dari fungsi religi ke fungsi rekreasi. Perhatian penonton terbagi ke dalam segmen pertunjukan yaitu menonton dari awal hingga akhir pertunjukan, menonton dari awal hingga segmen limbukan, menonton dari segmen limbukan hingga goro-goro. Faktor-faktor yang melatarbelakangi penonton yaitu: Karakteristik Dalang yang tampil, letak geografis pertunjukan, lingkungan keluarga, pengetahuan filosofi Jawa, kesibukan kerja dan sekolah (Ni'mah 2016).

Penelitian lain yang lebih dekat dengan seni pertunjukan wayang kulit di era digital adalah penelitian yang dilakukan oleh Arwin Purnama Jati berjudul "Spirit Seni Pertunjukan Tradisional Jawa dalam Media Digital yang Bersifat Mobile". Menurut Arwin Purnama Jati, seni pertunjukan Jawa seperti tarian, drama, musik yang bersifat tradisional masih memiliki eksistensi di masa kini yaitu di era digital. Pertunjukan itu pada umumnya digelar dengan caracara tertentu, yaitu menempati ruang, waktu khusus, ataupun menyasar pada penonton yang memiliki minat khusus atau dalam rentang usia yang dekat dengan masa kepopuleran seni tradisional tersebut. Kelahiran media digital menimbulkan pergeseran pada cara masyarakat menikmati seni pertunjukan Jawa. Sebagai contoh, masyarakat dapat menonton musik atau tarian Jawa melalui youtube. Efisiensi penikmatan seni pertunjukan tersebut menjadi salah satu kelebihan media digital, karena dapat dinikmati secara individual (private). Tulisan Arwin Purnama Jati ini mengkaji bagaimana media digital mendukung penikmatan seni pertunjukan tradisional Jawa dan bagaimana spirit seni pertunjukan tradisional dapat ditangkap oleh para penonton melalui media digital yang bersiat mobile (Jati 2020).

\section{Metode}

Penelitian ini menggunakan metode fenomenologi (Cresswell 2014). Peneliti melakukan observasi melalui proses pertunjukan wayang kulit oleh dalang viral Ki Seno di kanal youtube. Selain itu peneliti juga observasi langsung ketika dalang viral ini sedang melakukan pertunjukan wayang kulit di lokasi tertentu dan sedang live di kanal youtube. Informan yang diwawancarai mendalam adalah budayawan, tokoh masyarakat, penonton, pengrawit sesudah informan melihat pertunjukan dalang viral ini baik langsung di lokasi atau di kanal youtube sesuai perjanjian tentang bagaimana pandangan mereka tentang tema wayang kulit yang disiarkan melalui kanal youtube. Wawancara dilakukan 2-3 kali kepada informan. Data kualitatif yang diperoleh peneliti dientri, dikategori, direduksi dan dianalisis.

\section{Hasil dan Pembahasan}

Youtube telah mengubah Industri Media Online dengan dahsyat. Perkembangannya dimulai pada akhir 2005, di mana youtube yang merupakan keterkaitan antara gagasan media dan penggunaan media yang beorientasi pada layanan yang mencakup perusahaan-perusahaan media baru. Konten youtube tidak ditentukan oleh jaringan dan distributor yang ada, tetapi 
merupakan konten yang diproduksi oleh pengguna, yang produksinya dilakukan keluar jalur media arus utama untuk media online. Konten youtube di media online berupa unggahan video, bisa konten video komersial, popular maupun rumah tangga (Marshall dalam Holt dan Parren 2009: 87). Di jaman modern yang berbasis internet ini, fenomena youtube telah berkembang menjadi media, bukan sekedar media sosial yang mempertukarkan informasi antar pengguna, akan tetapi merupakan media penyiaran. Revolusi youtube sejak kehadirannya telah menyaingi media penyiaran TV, karena mampu mengurangi penonton TV. Fitur-fitur yang tersedia di youtube sangat menarik perhatian pengguna internet, bisa disaksikan melalui smartphone, tablet yang bersifat interaktif karena penonton bisa memberikan komentar langsung melalui smartphone yang dipegangnya sekaligus orang yang mengunggah video itu bisa segera membalas komentar penonton. Sifat asinkronus pada media baru sangat memungkinkan pengguna internet bisa menonton youtube kapan saja melalui rekaman. Kini, youtube mengembangkan fitur layanan baru berupa kemampuan live streaming, yaitu pengunggah video bisa melakukan aktifitas unggahan video secara siaran langsung melalui youtube tanpa harus merekamnya terlebih dahulu. Jadi youtube melayani dua bentuk siaran yaitu live streaming dan recording. Dalam tayangan di youtube tersedia berbagai layanan selain dua layanan utama yaitu layanan berbagi (Share), layanan unduhan (download), kolom komentar (live chat), penyimpanan (save), perhitungan jumlah penonton (views), jumlah penonton pelanggan (subscribers), penonton penyuka (like) dan penonton bukan penyuka (unlike), kolom keterangan pengunggah dan kolom tulisan untuk keterangan video unggahan (caption). Fenomena menarik dari pertunjukan wayang kulit di youtube, setelah beberapa kali menonton, yaitu jumlah penonton di youtube yang tercatat lewat views maupun subscriber cukup banyak.

Seni pertunjukan wayang kulit ini merupakan seni pertunjukan yang memerlukan penghayatan cukup dalam, bertele-tele, sehingga wayang kulit itu biasanya diminati penonton dari kalangan orang tua. Tetapi kehadiran seni wayang kulit dalam platform youtube tersebut mengubah pandangan masyarakat dalam menonton wayang kulit. Dalam format youtube ini muncul istilah dalang viral. Dalang yang dianggap paling viral saat ini karena memiliki paling banyak penggemar dan paling laris dengan jadwal pementasan tiap bulan rata-rata 20-25 kali ke berbagai tempat adalah Ki Seno Nugroho dari Yogyakarta. Dalang Seno Nugroho bertempat tinggal di Yogyakarta memiliki channel youtube bertitel "Dalang Seno" dengan subscriber 301.000 sejak 2 tahun ini. Setiap kali pentas dalam satu lakon secara live hingga selesai ratarata ditonton 30.000 penonton. Selain channel itu, Dalang Seno juga disiarkan secara live maupun rekaman oleh channel PWKS (Penggemar Wayang Ki Seno Nugroho) yaitu kelompok orang penggemar Dalang Seno. PWKS memiliki anggota tersebar diberbagai lokasi di seluruh Indonesia, yang diikat secara online melalui media sosial. Channel PWKS juga menyiarkan secara live streaming Youtube pentas wayang kulit Ki Seno Nugroho dan ditonton rata-rata 15.000 penonton tiap pentas. Beberapa Dalang yang lebih senior juga memiliki jumlah penggemar lewat youtube, tetapi jumlah penontonnya jauh lebih sedikit dibandingkan dengan Dalang Seno Nugroho.

Fenomena Dalang Seno dengan PWKS ini merupakan bentuk interaksi di dunia siber. Media baru membuka berbagai peluang untuk berinteraksi satu sama lain secara individual maupun kelompok sosial, memperluas ranah siaran, memperbanyak jumlah penggemar pertunjukan yang sudah tentu secara ekonomi merupakan konsumen. Aktifitas menonton seni pertunjukan wayang ini membutuhkan modal sosial antara lain penguasaan Bahasa Jawa, pemahaman konsteks kultural, memahami cerita utama pewayangan, seni sastra, dan musik Gamelan. Sekalipun modal sosial itu tidak harus dikuasai secara mendalam, karena kini seni pertunjukan wayang di media siber telah mengalami perubahan format untuk bisa diadaptasi ke selera penonton lebih luas. Dorongan orang untuk menjadi penggemar dan penonton wayang kulit 
karena beberapa dimensi dari pertunjukan tersebut antara lain perhatian terhadap alur cerita, ketangkasan dalang memainkan wayang kulit (sabetan), cara Dalang bertutur sehingga membuat penonton membangun daya fantasi, keruntutan cerita, dan keserasian pertunjukan. Menurut Sumarsam (2018), struktur, makna dan konteks seni pertunjukan terbentuk dan mengalami perubahan sesuai dengan perkembangan sejarah, termasuk perjumpaannya dengan konversi agama baru, perubahan sosial politik dan budaya, dan modernitas: era digital dan cyber space. Wayang juga merupakan seni pertunjukan multidimensi yang memiliki sejarah panjang, mengandung kedalaman estetika dan ungkapan simbolis, religiusitas, dan bagaimana wayang menyesuaikan dengan jamannya. Perubahan zaman berdampak pada formasi dan transformasi wayang, termasuk teknis pertunjukkannya, struktur, alur cerita dan iringan musiknya (Sumarsam dalam Dukut 2020). Nilai-nilai dalam pertunjukan wayang kulit mengandung kaidah-kaidah bangunan lakon atau struktur cerita, sehingga nilai yang digarap dalam pertunjukan adalah nilai kehidupan manusia, khususnya pandangan hidup orang Jawa. Konsep isi cerita mempunyai rasa atau penghayatan yang mencakup makna cerita, watak, atau karakter masing-masing tokoh cerita (Kresna 2012). Wayang tidak hanya pertunjukan lahiriyah, tetapi lebih bersifat rohaniah. Menurut Bayu Anggoro, seni pertunjukan wayang kulit merupakan warisan budaya Jawa yang mendunia, yang diperkirakan telah ada sejak kurang lebih 1500 Tahun SM. Wayang merupakan bahasa simbol kehidupan yang lebih bersifat rohaniyah dari pada jasmaniah. Setiap penonton yang melihat pagelaran wayang fokus perhatiannya bukan pada wayangnya, tetapi masalah yang tersirat dari tokoh pelaku wayang dalam pewayangan. Muatan nilai-nilai dalam pagelaran wayang menggambarkan nilai-nilai kehidupaan sehari-hari di masyarakat, gambaran manusia menempatkan diri pada tempat yang telah ditentukan oleh Tuhan. Tugas-tugas manusia di dunia mencakup memelihara, membina, memajukan negara; bangsa dan kemanusiaan. Tugas tersebut dalam istilah pewayangan adalah: mahayu hayuning projo, mahayu hayuning bangsa dan mahayu hayuning bawana (Anggoro 2018). Peran Dalang sangat besar untuk mensosialisasikan nilai-nilai sosial budaya yang terkandung dalam cerita wayang kulit agar bisa diterima dan diresapi penonton, menjadi tuntunan hidup manusia pada umumnya.

Pengakuan UNESCO terhadap seni pertunjukan wayang kulit sebagai Master Piece bagi masyarakat dunia menunjukkan bahwa, pertunjukan wayang kulit yang berasal dari tanah Jawa, bukan saja dimiliki oleh masyarakat Indonesia saja, tetapi juga dimiliki oleh masyarakat dunia. Bersamaan dengan pengakuan dunia itu, teknologi media baru membuka peluang bagi pertunjukan wayang kulit untuk bisa ditonton secara live streaming oleh masyarakat di berbagai belahan dunia. Melalui teknologi media baru juga memunculkan Dalang Wayang Kulit yang viral. Menurut Wejo Seno Yuli Nugroho yang meneliti fenomena Dalang wayang kulit era millenial, terdapat tiga dalang yang viral di media sosial yaitu Dalang Ki Seno Nugroho, Ki Sigid Aryanto, Ki Anom Dwijo Kangko. Ketiganya memiliki akun media sosial dan mengunggah pagelaran pertunjukkan wayang kulitnya melalui kanal youtube. Dari penelitian itu tercatat Dalang Ki Seno Nugroho memiliki jumlah penonton paling banyak diantara ketiganya (Wejo Seno Yuli Nugroho dalam Dukut 2020).

\section{Dalang Seno dan Penggemar Wayang Ki Seno Nugroho}

Mengenai PWKS para informan memberi penjelasan, bahwa Dalang Seno merupakan dalang yang digemari kalangan muda yang tergabung dalam Penggemar Wayang Ki Seno Nugroho (PWKS). Melalui wadah ini, penggemar dalang Seno tersebar di hampir seluruh wilayah Indonesia. PWKS memiliki cabang-cabang di wilayah Jawa Tengah, DIY, Jakarta, Bogor, Depok, Tangerang, Bekasi, cabang di Bandung, bahkan ada di wilayah luar Jawa seperti sebagian Sumatera, Kalimantan. Sekalipun demikian justru aktifitas menonton dari penggemar 
Dalang Seno berasal dari PWKS Jabodetabek. Hampir di setiap pentas Dalang Seno di berbagai daerah, yang juga live streaming lewat media sosial youtube, perwakilan PWKS Jabodetabek selalu ikut berpartisipasi mengambil gambar pementasan Dalang Seno. PWKS Jabodetabek memiliki kanal youtube sendiri bernama PWKS Channel, sehingga selalu melakukan live streaming pementasan Dalang Seno.

Dalang Seno memanfaatkan media youtube membentuk komunitas youtuber yang tergabung dalam PWKS. Komunitas ini kemudian berkomunikasi melalui Facebook, Twitter, Instagram. Melalui aktifitas PWKS di berbagai media sosial itu, Dalang Seno selalu mendapatkan perhatian besar dibandingkan dengan pementasan wayang kulit oleh dalang lain. Peran PWKS sebagai komunitas virtual sangat penting dalam membesarkan nama Dalang Seno. Menurut paparan informan, PWKS itu salah satu yang dimanfaatkan Dalang Seno sebagai senjata untuk menghangatkan suasana pertunjukan lewat kanal youtube. PWKS merupakan persatuan yang mengangkat nilai-nilai budaya, melalui kegiatan rutin, misalnya, pada bulan tertentu ada acara Ulang Tahun PWKS. Pada kesempatan ini para penggemar dari Jakarta, Bandung dan lain-lain hadir dalam sebuah acara sarasehan. Pada kesempatan pertemuan yang dilakukan di suatu tempat itu biasanya dimanfaatkan untuk menyampaikan kritik kepada Dalang Seno, memberi masukan, biasanya dihadiri Ki Seno Nugroho, sehingga terjadi diskusi yang dinamis. PWKS, bukan hanya sekumpulan penggemar umum tetapi juga terdiri dari seniman-seniman, pengamat seni, budayawan sehingga bila mereka berkumpul materi diskusi pewayangan terus berkembang. Suara hati penggemar di akomodasi lewat PWKS.

Grup PWKS Nusantara yang anggotanya sangat banyak terdiri dari kalangan SMA, Mahasiswa, SMKI, ISI, Kepala Desa, Anggota Dewan, dan golongan masyarakat lain. PWKS merupakan penyambung silaturahmi antar daerah, misalnya saat Dalang Seno menggelar Wayang Kulit di wilayah masyarakat Sunda, Jawa Barat, sekalipun mereka tidak memahami penggunaan bahasa Jawa kuno, mereka menyukai cerita wayang, tetapi mereka bisa memahami jalan ceritanya. Hal itu karena peran PWKS dengan kelompok-kelompok yang terdapat di wilayah-wilayah, membantu memberi pemahaman bahasa kepada mereka melalui diskusi PWKS dalam grup Virtual, memberi pemahaman tentang guyon-guyon/bersendagurau Dalang Seno. Komunitas itu berperan sebagai penterjemah.

Penonton youtube terdiri dari beraneka ragam kalangan dari berbagai negara, bila dari penonton itu banyak yang menjadi anggota grup virtual PWKS, tentu lebih mampu memahami bahasa dialog wayang Dalang Seno. Keanggotaan PWKS beraneka ragam seperti ada Anggota Dewan, mereka juga sangat memberi perhatian terhadap pagelaran wayang Dalang Seno, mereka selalu hadir di acara wayangan secara langsung, sekalipun bagi anggota dewan tidak ada kepentingan. Para penggemar mendokumentasikan secara lebih bebas dari pentas wayang Dalang Seno menggunakan ponsel mereka, di beberapa adegan. Pagelaran Wayang Kulit Dalang Seno merupakan tempat untuk berinteraksi berbagai kalangan yang tergabung dalam PWKS.

Menurut informan anggota PWKS:

Dalang Seno membawa crew khusus untuk live streaming youtube. PWKS secara khusus juga diberi lisensi oleh Dalang Seno untuk melakukan live streaming pada setiap pagelaran Wayang Kulit Dalang Seno. Jadwal pementasan Pagelaran Wayang oleh Dalang Seno disebarkan secara reguler melalui kanal resmi Dalang Seno sehingga tersebar di setiap komunitas. PWKS memiliki banyak nama yaitu PWKS Nusantara, PWKS Gunung Kidul, PWKS Kulon Progo, dan lain-lain. Informasi tentang aktifitas Dalang Seno berkembang melalui cara daring, yang membuka peluang untuk viral, hal itu merupakan promosi yang paling tepat. 
Secara brand image Dalang Seno dimata anggota PWKS merupakan dalang favorite dan menjadi idola mereka.

\section{Membangun Cerita Ringkes}

Dari sisi bercerita, Dalang Seno membawakan wayang kulit menggunakan dialog antar wayang yang mudah dipahami, bercerita dengan menggunakan bahasa yang tidak sulit. Kekuatan Seno yang lain saat mendalang sehingga menarik perhatian banyak penonton adalah penyampaian cerita dengan gaya guyon/bersenda gurau, jenaka. Dalam pementasan wayang kulit, Dalang Seno tidak sekedar membawakan cerita sesuai alur cerita secara terus menerus, tetapi seringkali ditimpali selingan yang menceritakan kehidupan yang dikenal penonton sehari-hari yang relevan dengan cerita pewayangan, menggunakan gaya bercerita lebih santai.

Dalang Seno memiliki pengamatan yang cermat pada perilaku penonton generasi kekinian yaitu apa yang dikehendaki penonton dicermati oleh Dalang Seno sebagai pasar potensial. Cerita yang dibangun Dalang Seno dilakukan secara ringkes/singkat, sehingga bisa dengan mudah dipahami penonton muda, komunikatif. Menurut informan, kata singkat dalam pagelaran wayang kulit Dalang Seno Nugroho, karena Seno berani mengambil cerita wayang itu secara sepotong, tidak tuntas. Misalnya cerita Brotoyudo, masyarakat biasanya disuguhkan cerita yang panjang, orang ingin melihat ceritanya, tapi Dalang Seno mampu menampilkan pemangkasan cerita untuk mengurangi kejenuhan penonton youtube sekarang. Dalang Seno berani menampilkan pagelaran yang berbeda dari Dalang yang lain dan berani berontak, yaitu berani mengangkat tokoh wayang Bagong dari kasta rendah yang berani melawan raja, berani melawan Baladewa. Misalnya seorang pimpinan atau pejabat harus disubyosubyo"/diagungkan atau dialembono/disanjung. Dalang Seno melihat orang mengalami kejenuhan dengan kultur pemimpin politik yang dihormati secara berlebihan. Cerita itu hanya bumbu, yang paling segar dan menarik dari Dalang Seno adalah kemampuannya menampilkan joke-joke nya yang segar, dan adegan pemberontakan secara politik yang justru seringkali dirindukan penonton. Tokoh Wayang Bagong melihat ketidakadilan atau kesalahan yang dilakukan oleh pemimpinnya, maka Bagong bisa memberontak. Pada kondisi ini Bagong dianggap mewakili kondisi masyarakat penonton sekarang. Penonton youtube tertarik dengan potongan-potongan pendek dagelan dan humor, lawakan yang menonjol dan sengaja dibangun untuk menarik perhatian mereka.

Meringkas cerita wayang kulit merupakan siasat Dalang untuk mengejar nilai hiburan dari pagelarannya agar mendapatkan perhatian lebih besar dari penonton masa kini, yang lebih menyukai adegan-adegan yang tidak panjang (bertele-tele). Dari sisi market, Dalang Seno berhasil mendapatkan apresiasi penonton youtube karena setiap kali pentas, sebelum wabah Covid 19 ini, di tonton lebih dari 100.000 penonton youtube dengan subscriber lebih dari 300.000 orang. Meskipun menurut informan:

"Jumlah penonton yang berjumlah banyak secara daring ini, tidak semua memahami filosofi yang terkandung dalam cerita wayang. Penonton sekarang lebih menyukai cerita ringkes itu, sekalipun membawa konsekuensi pada kurang dicermatinya filosofi dalam ceritanya. Filosofi dalam cerita wayang bagi sebagian orang yang memahaminya merupakan nilai penting yang harus dicermati. Cara mencermatinya justru bisa tidak secara langsung saat menonton pagelaran wayang itu. Kebanyakan orang Jawa memiliki cara bergaul berbasis sopan, ramah, tutur kata yang baik. Orang Jawa menonton wayang kulit untuk memantapkan perilaku berkebudayaannya, sebab melalui cerita wayang yang disampaikan Dalang, perilaku berkebudayannya sudah 
terwakili, artinya dalam cerita wayang itu unsur-unsur perilaku berkebudayaan orang Jawa ada di dalamnya. Pada jejer/tampilan pertama hingga jejer akhir pagelaran, kurang mendapat perhatian dari penonton. Penonton di pagelaran biasanya akan memenuhi panggung, dan mereka kebanyakan mendekati panggung langsung pada adegan limbukan dan goro-goro. Padahal jejer awal cerita penuh filosofi."

Seorang informan mengemukakan "berontak" dalam pengamatannya terhadap Dalang Seno, dan menjelaskan bahwa, pada jaman orde baru melakukan kritik kepada pemerintah, pejabat, akan kena semprit (peringatan), dibredel, ijin terbit tidak dikeluarkan. Kini jaman keterbukaan Dalang Seno berani meneriakkan kondisi ketidakadilan, saat negara kita mengalami bencana pandemi Covid 19, yang berdampak pada kesulitan masyarakat secara ekonomi. Dalang Seno memanfaatkan Bagong meneriakkan protes kepada Baladewa yang digambarkan sebagai representasi Pemerintah sekarang, yang menerapkan berbagai aturan untuk mengurangi resiko penularan Covid 19, seperti

“...masyarakat dipenging-pengin ning sampeyan gawe peraturan ning ora gawe solusi, keno sampeyan gawe peraturan, diperpanjang keno, tanggap darurat nganti tekan suk tahun 2444 rapopo. Ning masyarakat weh ono solusi pie carane golek pangan, ora ming gawe peraturan thok. Paham ora kowe, iki atiku ki loro nek carane ngene iki, podo melet-melet, podo kangelan golek sandang pangan. Luwih-luwih koyo kulo niki seniman koyo Aku karo Gareng karo Petruk niku, nganti ora biso obah. Keno gawe peraturan ning kasih solusi pada masyarakat. Seniman baiknya seperti ini kasih solusi, seniman oleh pentas ning penonton terbatas. Ngono pie? Ora sak penake dewe, loro ning ati, nek aku ngelih ora popo, ning bojoku ngelih, anakku ngelih... Rasane pie dadi kawulo cilik koyo penyanyi, tukang keyboard, sound sistem modar kabeh... kudu mbok pikirke... ojo sak karepe dewe, ayo podo nyuoro ben podo mikirke." (Cuplikan dialog dari Lakon Bagong Gugat oleh Dalang Seno).

(Terjemahan: masyarakat dilarang, tetapi saudara membuat peraturan tanpa membuat solusi, silahkan anda buat aturan, diperpanjang pelaksanaan aturan silahkan, tanggap darurat hingga tahun 2444 silahkan. Tetapi masyarakat berikan solusi mengenai bagaimana caranya mencari makan, tidak hanya asal membuat peraturan saja. Paham apa tidak saudara, ini hatiku sakit kalau caranya seperti ini, masyarakat menjulurkan lidah, kesulitan mencari sandang dan makan. Terlebih lagi seperti saya ini seniman, juga Gareng dan Petruk itu, hingga tidak bisa beraktifitas. Silahkan buat peraturan tetapi berikan solusi kepada masyarakat. Seniman sebaiknya beraktifitas seperti ini kasih solusinya, seniman boleh berpentas tetapi jumlah penonton dibatasi. Bagaimana bila seperti itu? Tidak lalu bertindak sewenang-wenang, membuat sakit hatiku, kalau saya kelaparan tidak masalah, tetapi istriku yang kelaparan, anakku yang kelaparan... rasanya bagaimana menjadi orang di kelas bawah seperti penyanyi, pemain keyboard, operator tata suara, semuanya mati...harusnya saudara pikirkan... jangan bertindak sewenang-wenang, ayo kita menyuarakan ini agar semua ikut berpikir.)

Dengan suara keras dan lantang, Dalang Seno memainkan Wayang Bagong untuk memprotes Pemerintah yang membuat berbagai peraturan pencegahan Covid-19. Peraturan itu berupa Protokol Kesehatan yang wajib di taati seluruh masyarakat dengan mewajibkan masyarakat tanpa kecuali untuk menggunakan masker, menjaga jarak sosial dengan orang lain, sehingga melarang orang berkerumun, selalu mencuci tangan. Dampak peraturan itu pada masyarakat adalah merosotnya secara tajam kegiatan ekonomi, sehingga masyarakat mengalami kesulitan hidup selama beberapa bulan. Bagong meneriakkan ketidakadilan bahwa Penguasa melalui tokoh Baladewa, hanya berfokus pada peraturan yang bersifat tunggal, tanpa memikirkan nasib 
seniman seperti penyanyi, pemain keyboard, pemusik, persewaan sound sistem yang tidak bisa lagi berpentas, sehingga mengakibatkan perekonomian mereka hancur.

Dalam suatu adegan wayang kulit Dalang Seno, saat Bagong memberontak kepada Baladewa maupun Kresno seperti itu menjadi tontonan menarik. Adegan itu menurutnya merupakan adegan yang dirindukan masyarakat sekarang. Perubahan terletak pada kondiri keterbukaan yang lebih luas, sebab masyarakat masih mentaati aturan itu, masih menggunakan toto kromo. Kehadiran Dalang Seno dengan adegan "berontak" itu merupakan wujud keterbukaan secara politik di era kini, sehingga bisa jadi merupakan media politik praktis yang mewakili suara masyarakat. Masyarakat kita saat ini masih memerlukan media (ruang) untuk membangun keserasian komunikasi di masyarakat.

Pengertian "berontak" dalam seni itu bukan berarti nilai filosofinya tidak tersampaikan, tetapi keterbatasan bahasa Jawa yang sulit dipahami. Pada tataran ini Dalang Seno bisa menunjukkan bahwa penggunaan bahasa Jawa "kromo" bisa diatasi dengan gaya mendalang yang membangun cerita dengan menggunakan bahasa Jawa "ngoko" yang hampir semua kalangan di Jawa bisa memahami. Informan lain mengemukakan mengenai cerita wayang yang diringkas. Pemahaman tentang ini ada pada adegan awal (jejer awal) bisa terjadi tidak melakukan dialog lengkap, lebih banyak kosong, hanya dialog pada hal-hal yang diangap penting oleh Dalang, juga tidak semua tokoh wayang yang ditampilkan tidak semua saling berdialog. Setelah adegan Limbukan, mulai dari perang kembang, semestinya permusuhan semua tokoh wayang kulit dilibatkan dalam perang, tetapi Dalang Seno hanya memainkan tokoh Wayang Kulit satu atau dua tokoh wayang saja yang dilibatkan dalam perang. Lain halnya dengan wayang kulit jaman dulu, ceritanya berpanjang-panjang (nggladrah, tidak fokus). Ketika berakhirnya adegan Panakawan (Goro-goro), yang menurut informan diistilahkan dengan "Punokawan Bedol" masih ada perang cakilan, tetapi Dalang Seno tidak pernah memunculkan perang Cakilan. Pada adegan Perang Brubuhan hanya dipilih tokoh wayang tertentu yang ditampilkan sebagai akhir (ending) lakon, misalnya lakon tentang Werkudoro akhir ceritanya hanya ditampilkan Werkudoro saja. Cerita wayang yang diringkas itu artinya hanya diambil adegan-adegan yang menurut Dalang Seno dianggap penting saja, isi cerita tidak mengalami perubahan, tetapi alur cerita sudah pasti berubah lebih pendek. Memang dalam cerita wayang kulit terdapat nilai-nilai kemanusiaan yang terkandung di dalamnya, Dalang Seno nampaknya mengutamakan nilai hiburan bagi penonton, seperti dialog Bagong dengan Baladewa yang sangat lucu dan menghibur, padahal secara kelas sosial Baladewa adalah raja yang harus dihormati Bagong sebagai abdinya. Dalam dialog itu seharusnya kewajiban Bagong sebagai abdi menggunakan bahasa Jawa "Kromo Inggil" saat berbicara dengan rajanya yaitu Baladewa. Bagong marah besar kepada rajannya itu karena mengambil kebijakan yang merugikan rakyatnya saat terjadi bencana besar.

\section{Gending/Musik Pengiring Garapan}

Pementasan wayang kulit merupakan kesatuan pentas dari berbagai unsur seni Jawa yaitu seni suara, seni musik, seni tutur, seni pentas dengan perangkat yang terdiri dari Wayang Kulit, Dalang, Gamelan, Wiyaga (penabuh Gamelan), Pesinden, Geber (layar lebar untuk memainkan tokoh wayang kulit). Unsur-unsur pendukung lain yang lebih penting adalah adanya sistem tata suara, tata cahaya yang memadai, panggung, tarub hajatan. Pementasan wayang kulit pada umumnya diselenggarakan pada malam hari, mulai jam 21 - jam 03.00 (6 jam) namun menjadi 3 jam saat pandemi. 
Tata cahaya dan tata suara yang baik dan lokasi yang cukup luas untuk menempatkan berbagai unsur itu, merupakan pendukung teknis yang sangat diperlukan untuk keberhasilan pementasan, dan kenyamanan bagi penonton menikmati pagelaran. Penonton merasakan pakeliran/pementasan wayang kulit dalang Seno sangat nyaman dinikmati sebagai hiburan. Dalang Seno memahami tidak semua penonton muda usia menggunakan bahasa Jawa Halus (Kromo), bahkan kesulitan memahaminya, sehingga dialog dalam setiap adegan wayang kulit hampir semua digunakan bahasa Jawa sederhana (ngoko) yang mudah dipahami penonton muda. Penonton youtube cenderung menyukai pagelaran seni budaya, terutama pentas klasik yang tidak menggunakan alat modern seperti keyboard. Keinginan penonton itu diakomodasi Dalang Seno dengan menyuguhkan tontonan pagelaran wayang kulit tanpa iringan musik diatonis, tetap mempertahankan musik klasik. Sekalipun demikian tontonan yang disuguhkan tetap segar, enak ditonton, bisa dipahami, humor-humor yang menyenangkan. Crew dan pesinden, pengrawit sering dilibatkan dalam pagelaran secara utuh, tidak berperan secara terpisah-pisah.

Penonton tidak hanya sekedar menonton wayang tetapi menonton seluruh pagelaran dalam panggung wayang itu. Penonton akan menonton Dalang, Pengrawit, Sinden, bintang tamu saling berinteraksi dalam dialog, di satu panggung. Contoh dulu Sinden hanya me "nyinden" tetapi sekarang dilibatkan dalam dialog saat adegan Limbukan dan adegan Goro-goro. Di masa kini wayang kulit mengalami beberapa perubahan berupa hadirnya inovasi alat musik kontemporer, adanya tambahan alat musik diatonis yang berasal dari Negara Barat sebagai pelengkap Gamelan yaitu drum, terompet, keyboard. Peralatan musik tambahan ini biasanya dimainkan pada adegan Limbukan untuk mengiringi jenis lagu-lagu "campursari". Pada adegan Limbukan, Dalang memanfaatkan musik untuk melakukan interaksi dengan penonton di panggung maupun penonton streaming youtube, sinden, penabuh Gamelan, bintang tamu pelawak.

\section{Fungsi Menghibur}

Pada adegan brubuhan tokoh-tokoh wayang, ditambahkan tokoh-tokoh carangan yang mengacu pada cerita aslinya. Menurut penonton:

"Cara peyampaian tokoh-tokoh wayang carangan itu oleh Dalang nampak berbeda dengan tokoh wayang pakem. Makna filosofi pada pagelaran wayang jaman dulu dengan sekarang memiliki perbedaan. Pagelaran wayang kulit jaman dulu sekedar melestarikan budaya dan berfungsi sebagai penyebaran agama Islam, tetapi jaman sekarang merupakan media curahan hati masyarakat. Pakem itu pengertiannya berrmacam-macam. Ada Dalang yang menafsirkan tiap adegan, tetapi Dalang Seno menafsirkan pakem itu terletak pada trah atau struktur keturunan dari tokoh wayangnya. Misalnya Gatotkaca itu secara pakem adalah anak Werkudoro, jadi bila bukan pakem bisa jadi Gatotkaca anaknya Sengkuni, anaknya Suryudono. Maksudnya adalah bahwa Dalang Seno sangat ketat dengan memegang pakem dari struktur keturunan ini, sehingga lebih bebas membangun cerita wayang dengan alur yang tidak menurut cerita baku (pakem) dari cerita turun temurun."

Format pagelaran wayang kulit Dalang Seno seperti sekarang ini cukup menghibur penonton, sekalipun penonton nampaknya kurang memberi perhatian pada filosofi yang terkandung dalam seluruh cerita.

Apabila Dalang jaman sekarang masih membawakan atau mengikuti cerita pakem sudah bisa dipastikan tidak akan mendapatkan perhatian banyak penonton, bahkan mungkin tidak disukai 
penanggap. Contoh Dalang yang dianggap dalang jaman dulu dan mengikuti pakem menurut Sutino adalah Ki Timbul Hadi Prayitno (almarhum). Dalang Seno mengikuti selera pasar karena berbasis pada konsep utama wayang kulit harus dilestarikan, wayang kulit masih ada, masih di tanggap orang untuk berbagai acara hajatan, masih merupakan pagelaran penting, hingga sekarang.

Secara umum, para informan membaca pagelaran wayang kulit Dalang Seno lebih menonjolkan fungsi hiburan diberbagai adegan, yang mampu menarik berbagai kalangan penonton lewat youtube. Beberapa kemudahan menonton pagelaran wayang kulit diberikan kepada netizen, karena youtube memiliki fiture-fiture seperti fasilitas download yang memungkinkan pengguna mengunduh file itu untuk bisa menonton ulang tanpa menggunakan kuota pulsa. Fasilitas sharing merupakan fiture yang disediakan untuk berbagi konten dengan pengguna lain. Fiture Save atau simpan, pengguna bisa menyimpan konten youtube agar bisa ditonton tunda. Melalui media sosial youtube, pengguna bisa memberikan komentar secara interaktif dengan para pengguna lain maupun dengan youtuber. Karakter media sosial ini juga bersifat recording yaitu program live streaming selanjutnya bisa ditonton ulang setelah seluruh program selesai. Kemudahan-kemudahan media saat ini, dengan konten wayang kulit yang sangat padat aspek hiburan, nampaknya selaras dengan karakter netizen youtube yang ingin mendapatkan hiburan murah, mudah, asinkronous, interaktif.

Fungsi menghibur pagelaran wayang kulit oleh dalang Seno yang disiarkan lewat media online sangat mengemuka, tetapi belum pasti menjadi penyebab bagi kemungkinan berkurangnya intensitas sosialisasi nilai sosial budaya sebagai esensi pagelaran. Orang Jawa yang mengenal wayang kulit sudah terdidik sopan santun sejak kecil, hal ini karena sosialisasi nilai sosial di masyarakat Jawa yang intens. Mereka terbiasa menggunakan aturan-aturan atau norma-norma berbicara menggunakan bahasa Jawa sehari-hari yang diajarkan oleh orang tua mereka. Dalam dialog wayang yang menggunakan bahasa Jawa, dengan isi cerita yang sarat dengan tuntunan hidup, tatanan berbahasa dengan orang yang lebih tua, merupakan keseharian pergaulan masyarakat Jawa. Jadi tuntunan maupun tata cara berbahasa dalam cerita wayang kulit, hanya mengulang dari peristiwa yang ada di masyarakat, yang memungkinkan masyarakat penonton wayang itu mengalami kejenuhan. Sempat beberapa tahun lamanya pagelaran wayang kulit sepi penonton di panggung. Karena saat itu, sebelum didukung teknologi digital, pegelaran wayang kulit disimpan dalam media suara pita Cassette dan bisa dibeli di toko-toko dengan harga relatif murah. Pilihan ini menjadikan penonton memilih mendengarkan wayang kulit lewat pemutar kaset karena bisa didengarkan ulang. Kejenuhan penonton saat itu nampaknya di tanggapi Dalang Seno dengan memainkan gaya mendalang dan bercerita yang membuat penonton merasa mendapatkan kesegaran saat menonton wayang kulit secara langsung, misalnya menampilkan tokoh-tokoh kontraversial berhadapan dengan tokoh-tokoh panutan.

Penonton wayang saat ini mengalami pergeseran cara berpikir secara umum juga khususnya terhadap wayang, terutama pada pemahaman nilai sosial budaya penonton terhadap wayang. Sudah beberapa dekade ini pelajaran berbahasa Jawa, pelajaran berbudaya Jawa di hampir semua anak-anak kecil sudah tidak diajarkan secara baik, tetapi mereka diwajibkan belajar berbahasa Indonesia dengan kebudayaannya yang lebih luas cakupannya. Perubahan penggunaan bahasa ini sudah barang tentu menghilangkan kosakata berbahasa mereka, menghilangkan beberapa perbendaharaan kata dalam bahasa Jawa. Pola pikir anak-anak itu mengalami pergeseran, dan ini mempengaruhi pola perilaku pergaulan sehari-hari. Perubahan nilai sosial budaya karena perubahan tata bahasa Jawa di masyarakat yang tidak lagi diajarkan, diakomodasi Dalang Seno dengan mengubah penggunaan tata berbahasa di pagelarannya yang lebih fleksibel, sesuai kemampuan berbahasa oleh penonton. Dalang Seno menampilkan 
adegan dalam cerita wayang menitikberatkan bukan pada unggah ungguh/sopan nya dialog, sekalipun orang Jawa unggah ungguh luar biasa kuat. Dalam adegan-adegan itu di gambarkan melalui representasi Panakawan, terutama Bagong, bahwa rakyat kecil tidak harus menyembah ke Ratu. Menurut informan:

"Dalang Seno berhasil mengemas adegan yang sebenarnya penuh dengan tidak adanya unggah ungguh antara abdi dengan Ratunya, melalui guyonan/joke-joke lain. Saat Bagong akan pulang ke rumahnya di Karang Kadempel minta ongkos Prabu Baladewa, hal ini jelas tidak menunjukkan kesopanan, kemudian karena tidak di respons Prabu Baladewa, maka Bagong beralih minta kepada patihnya untuk dimintakan ganti kepada Baladewa, agar patihnya minta ganti dari Prabu Baladewa. Adegan tersebut bila dilihat dari tata kebiasaan pergaulan secara adat Jawa menunjukkan ketidaksopanan, tidak ada unggah ungguh, kui nyangklak banget, wong cilik kok nyangklaki ratu, meski ora nyembah tapi unggah ungguh ki kudu dijunjung abdi koyo Bagong, kudu duwe sopan (itu tidak menghormati sekali, orang kecil koq tidak menghormati pimpinan. Meskipun tidak harus menyembah tetapi sopan santun harus dijunjung bawahan seperti Bagong itu harus sopan pada pimpinannya)."

Dalam adegan-adegan seperti itu, Dalang Seno menganggap semua orang sama, hanya peran yang membedakannya, karena orang memiliki derajad tinggi akan lengser juga. Adegan semacam ini bagi penonton orang-orang tua merasakan tidak nyaman menonton adegan itu.

Kalangan penonton sepuh/tua, yang sudah mempunyai banyak pengalaman menonton berbagai pertunjukan wayang kulit mengemukakan bahwa mereka tidak merasakan "menonton wayang kulit sesungguhnya". Pernyataan itu dikemukakan oleh seseorang penonton sepuh yang sempat menonton secara langsung di panggung pagelaran Dalang Seno. Komentar itu muncul dari seorang penonton sepuh yang cermat karena memiliki pengalaman menonton pagelaran wayang kulit di berbagai Pakeliran. Fungsi hiburan yang menonjol dari Dalang Seno telah menggerus makna cerita wayang kulit. Perbedaan cara menonton terhadap pagelaran Dalang Seno merupakan pro-kontra penonton menyikapi cara mendalang Dalang Seno. Dengan sedikit menyimpulkan seorang informan mengemukakan:

"Memang benar banyak pro-kontra di penyajian pakeliran Dalang Seno, terutama kalangan sepuh yang kritis terhadap kehormatan, memahami unggah-ungguh. Menonton Pagelaran Dalang Seno nampaknya mengalami ketidakpuasan, karena beberapa dialog lakon dalam adegan sering tidak menunjukkan tatanan unggah-ungguh dalam berbahasa. Contoh yang sedang viral, Bagong berani dengan Prabu Baladewa, kemudian Bagong juga berani dengan Bapaknya sendiri yaitu Semar, Bagong sering berbahasa dengan tidak sopan, sering berbahasa tanpa mempedulikan lawan bicara. Sebagian penonton sepuh yang merasa tidak nyaman dengan adegan tersebut tidak memberikan komentar, tetapi justru adegan itu merupakan adegan yang mendapat perhatian dan dikagumi banyak penonton."

Kondisi masyarakat sekarang yang sangat memerlukan smartphone yang bahkan perilaku berkomunikasi mengalami pergeseran besar, karena fungsi teknologi tersebut bukan hanya sekedar untuk menelpon dan mengirim pesan singkat, tetapi hampir semua aktifitas kehidupannya menggunakan alat itu. Kebutuhan ini diakomodasi oleh Dalang Seno, karena merupakan realitas market baru. Dalang jaman sekarang, dimana konsumen merupakan generasi baru yang hidup dengan smartphone yang dikenal dengan generasi millenial, bila tidak bisa mengadaptasi cara mendalang, mengubah adegan dan cerita maka dalang itu akan sepi penonton. Semua informan mengakui bahwa Ki Seno telah mengalami pencapaian sebagai 
Dalang dengan jumlah penggemar (fans) yang banyak. Fans butuh hiburan, sehingga untuk mensiasati supaya mendapat banyak penonton dan banyak orang yang menanggap wayang kulit, maka dalang Seno menonjolkan hiburan. Karena itu sisi filosofi makna atau ceritanya kurang mendapat perhatian orang saat ini.

\section{Simpulan}

Pandangan penonton bahwa mereka merasa senang nyaman menikmati wayang kulit di kanal youtube sebagai hiburan. Alasan mereka bahwa dalang Seno membangun cerita wayang kulit dengan lebih ringkas, ada beberapa adegan dan dialog yang dipersingkat, tetapi tidak mengubah keselururan alur cerita aslinya. Alur cerita tidak lagi te rkesan panjang dan lama, sehingga tidak membuat jenuh, dan mudah dipahami, komunikatif. Meringkas cerita wayang kulit merupakan siasat Dalang untuk mengejar nilai hiburan dari pagelarannya agar mendapatkan perhatian lebih besar dari penonton masa kini, yang lebih menyukai adegan tidak panjang.

\section{Daftar Pustaka}

Anggoro, B. (2018) Wayang dan Seni Pertunjukan: Kajian Sejarah Perkembangan Seni Wayang di Tanah Jawa sebagai Seni Pertunjukan dan Dakwah. Juspi: Jurnal Sejarah Peradaban Islam, 2 (2): 123.

Ardika, I G. (06 Maret 2010), Unesco Akui Wayang Sebagai Masterpiece Budaya Dunia. https://wayang.wordpress.com/2010/ jam 9.15.

Cresswell, J. W. (2014) Penelitian Kualitatif dan Design Riset. Yogyakarta: Pustaka Pelajar.

Dukut E. M. (Edt.) (2020), Kebudayaan, Ideologi, Revitalisasi dan Digitalisasi Seni Pertunjukan Jawa Dalam Gawai, Semarang: Universitas Katolik Soegijapranata.

Holt, J. dan Parren, A. (Edt.) (2009) Media Industries: History, Theory, and Method. London: Wiley-Blackwell Publishing.

Jati, A. P. (2020) Spirit Seni Pertunjukan Tradisional Jawa dalam Media Digital yang Bersifat Mobile. Dalam Kebudayaan, Ideologi, Revitalisasi dan Digitalisasi Seni Pertunjukan Jawa Dalam Gawai, Ekawati Marhaenny Dukut (Edt.). Semarang: Universitas Katolik Soegijapranata.

Kresna, A. (2012) Mengenal Wayang. Yogyakarta: Laksana.

Ni'mah, S. (2016) Respon Generasi Muda Jawa Terhadap Seni Pertunjukan Wayang Kulit (Studi Kasus di Desa Lemah Ireng, Kecamatan Bawen, Kabupaten Semarang. Skripsi Pendidikan Psikologi dan Antropologi Universitas Negeri Semarang.

Sumarsam (2018) Memaknai Wayang dan Gamelan, Temu Silang Jawa, Islam, dan Global. Yogyakarta: Gading. 